\title{
ITSN1 Gene
}

National Cancer Institute

\section{Source}

National Cancer Institute. ITSN1 Gene. NCI Thesaurus. Code C105657.

This gene plays a role in both signal transduction and endocytosis. 